\title{
Cult Sites in Northern Sweden
}

\author{
By STEFAN BRINK
}

\section{Introduction}

The pagan cult in northern Sweden, i.e. Norrland, has for some decades been a neglected chapter in our history, a situation which unfortunately applies to Sweden as a whole, at least where onomastics are concerned (Cf. Hellberg 1986, 41 ff.; cf. Brink 1984a, 169 f.). An overall picture is still missing. For orientation in this area in Norrland one would have to consult Jan de Vries' in many aspects obsolete work Altgermanische Religionsgeschichte (1956-57), an even older paper by Gösta Bucht, Hedniska kultorter i mellersta Norrland (1920) and some other scattered papers (Lundgren 1878, passim; Nordlander 1881; Bucht 1923, 4 ff.; Hellberg 1984, $139 \mathrm{f}$.). This paper is therefore an attempt to overcome, if possible, this unsatisfactionary situation. The aim is thus to deliver an overview of the evidence that we have of preChristian religious activities in these northern parts - in this aspect, onomastic material is nearly almost all we have got - and some general remarks about the conversion to the new Christian religion. The area of investigation is what in the (Swedish) medieval period was known as Norrland (cf. fig. 1), hence the province of Gästrikland is left out. In other words, the part of Sweden considered here is modern Central Norrland.

With our state of knowledge of today it is not so easy to pick out the place-names that have denoted some kind of pagan cult activity. The place-name material can be divided into:

1. theoforic place-names

2. place-names denoting the site of a pagan cult, which do not however contain theoforic elements

3. place-names with a possible pagan cultic element. 


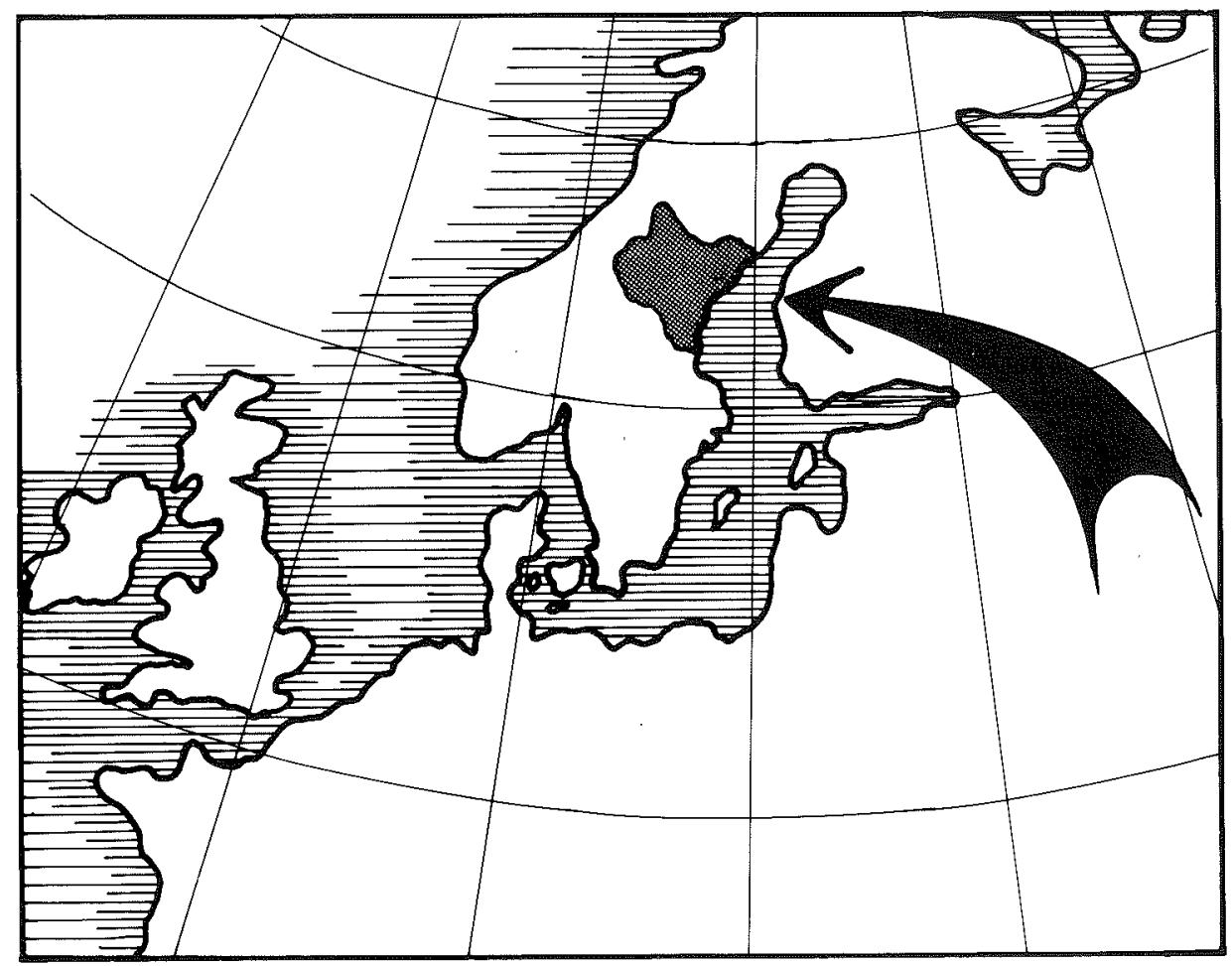

Fig. 1. Area of research - Central Norrland, Northern Sweden.

One may also wonder to what extent these pre-Christian cultic placenames have been preserved to the present day. Such a question is of course impossible to answer. The reason that we can obtain an insight into these ancient situations is due to the fact that farms and hamlets arose beside the ancient pagan cult centres and acquired their names from the neighbouring cult site (Cf. Hellberg 1986, 66). It is thus in the form of settlement-names that these cultic place-names have been preserved until today. In some instances one can perhaps reconstruct some old cultic place-name from field- or nature-names, but it seems reasonable to assume that in these cases, too, the indications are due to lost settlements.

Let us begin by examing the simplex place-names $V i$ and $H o v$, both regarded as having denoted pagan cult sites (see fig. 2). 


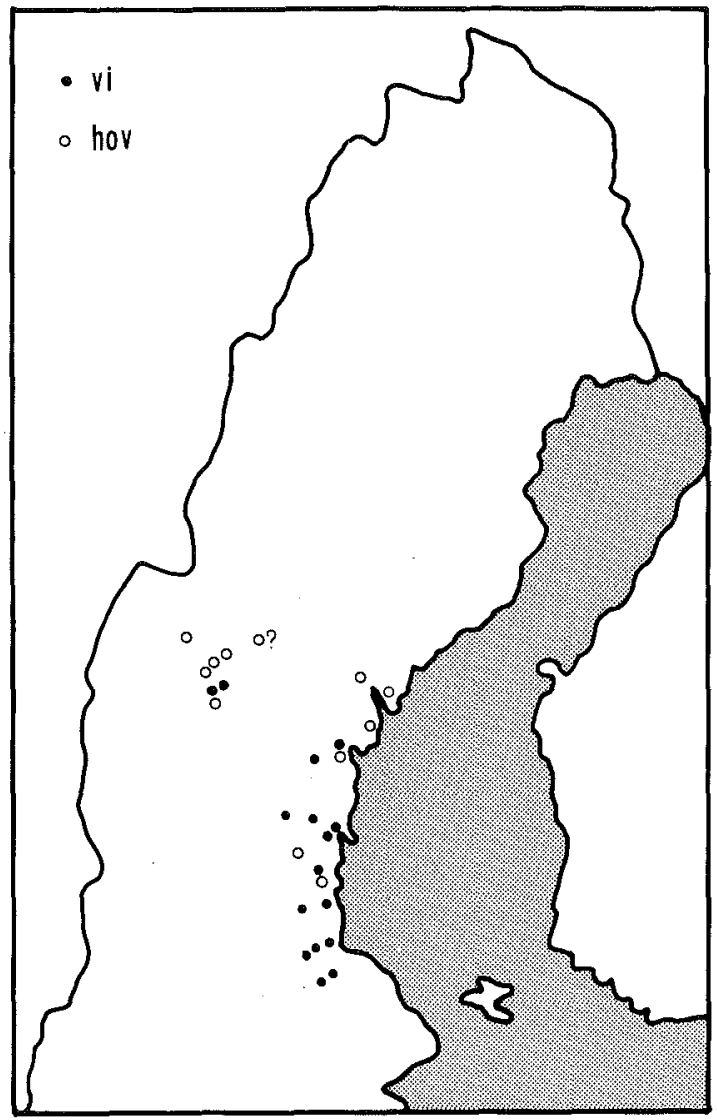

Fig. 2. The Norrland vi- and hov-names, denoting pagan cult sites (cf. the text).

\section{Place-names denoting a pagan cult site}

\subsection{Hov}

In the case of Hov, one must be careful, since this place-name element obviously also had secular meanings, denoting some kind of upheaval in the terrain or a court, house, hall etc. (Cf. Andersson 1986; cf. Olsen 1966). ${ }^{1}$ In each case, therefore, one must examine a place-name of this kind semanticly (i.e. "Realprobe"), to find out the original denotation for that particular place-name. The word hov goes back to a Protogerm. *huba- 'upheaval, vaulting'; in e.g. Norw. hov n. 'small

1 The latter meaning is especially found on the continent. 


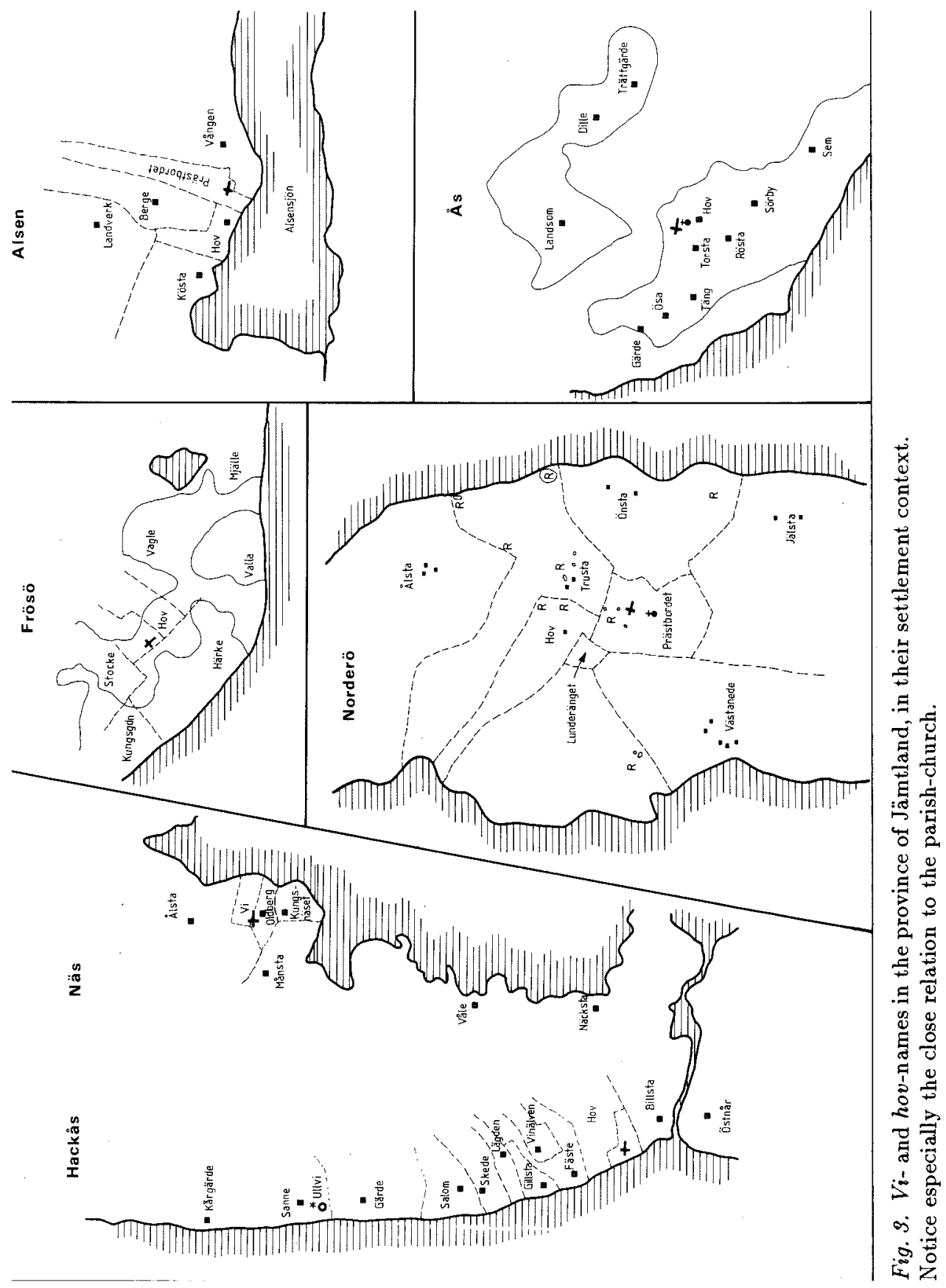


hillock', MHGerm. hübel 'hillock' (See Hellquist 1948, 365). How the sacral meaning has evolved is rather unclear (Andersson 1986).

Hov-names in Norrland are primarily found in the province of Jämtland, where there are five, perhaps six names; i.e. in the parishes of Hackås, Ås, Alsen, Norderö and Frösö (cf. fig. 3). They all have a very characteristic situation, normally being the name of the land belonging to the church or the vicarage, or situated in the immediate vicinity of the church. In most cases it is not possible to suggest an interpretation connected with some upheaval in the terrain, which makes it a most likely assumption that these names are evidence of pagan cult centres. This is also how these names have normally been regarded in the past. The present site of the church, on or in direct spatial contact with the pre-Christian cult site, must be understood as a kind of continuity of the sacral meeting place in each settlement district. A plausible assumption from this fact seems to be that there can hardly have been any state of tension between two competing religions, at least not for any longer span of time. It seems more reasonable to conclude that - as on Iceland - a collective agreement for conversion to the new religion, a decision perhaps taken at a regional council, took place. How much Östman's, Gudfasts son, words on the only runestone from the province of Jämtland on Frösön, which says that he christianisized the whole of Jämtland - austmą [r] kubfastarsun ... [li]t kristna eątalant - may be relied upon is uncertain, but at least one scholar emphasizes this fact and assumes that this Östman was the head of the provincial council (fig. 4) (Jansson 1977, 119 f.; cf. Friesen 1928, 66). N. Ahnlund (Ahnlund 1948, 125) commented on the hov-settlements of Jämtland and regards these places as having in older times possessed "a public temple, which we may see in relation with a meeting place". He furthermore stresses the fact that only one hov-name is found within a thing-district (Swed. tingslag). This could be taken as an indication that the pagan cult and legal matters were closely linked during pre-Christian times.

It is more uncertain whether Hovslägden (Hoffzlegde 1568, JR 2, 49) and Hovsåkern in the hamlet Prisgard in the parish of Lit are reminiscences of an older *Hov, which Carl Lindberg (Lindberg 1933, 28 ) has advanced as a hypothesis. The site is peripheral, several kilometres from the church and the central settlements in the parish (fig. 5).

The settlements in Lit and Häggenås are particularly interesting and require a study of their own. Here we find some probably ancient settlements - judging from their names - in peripheral sites in the 


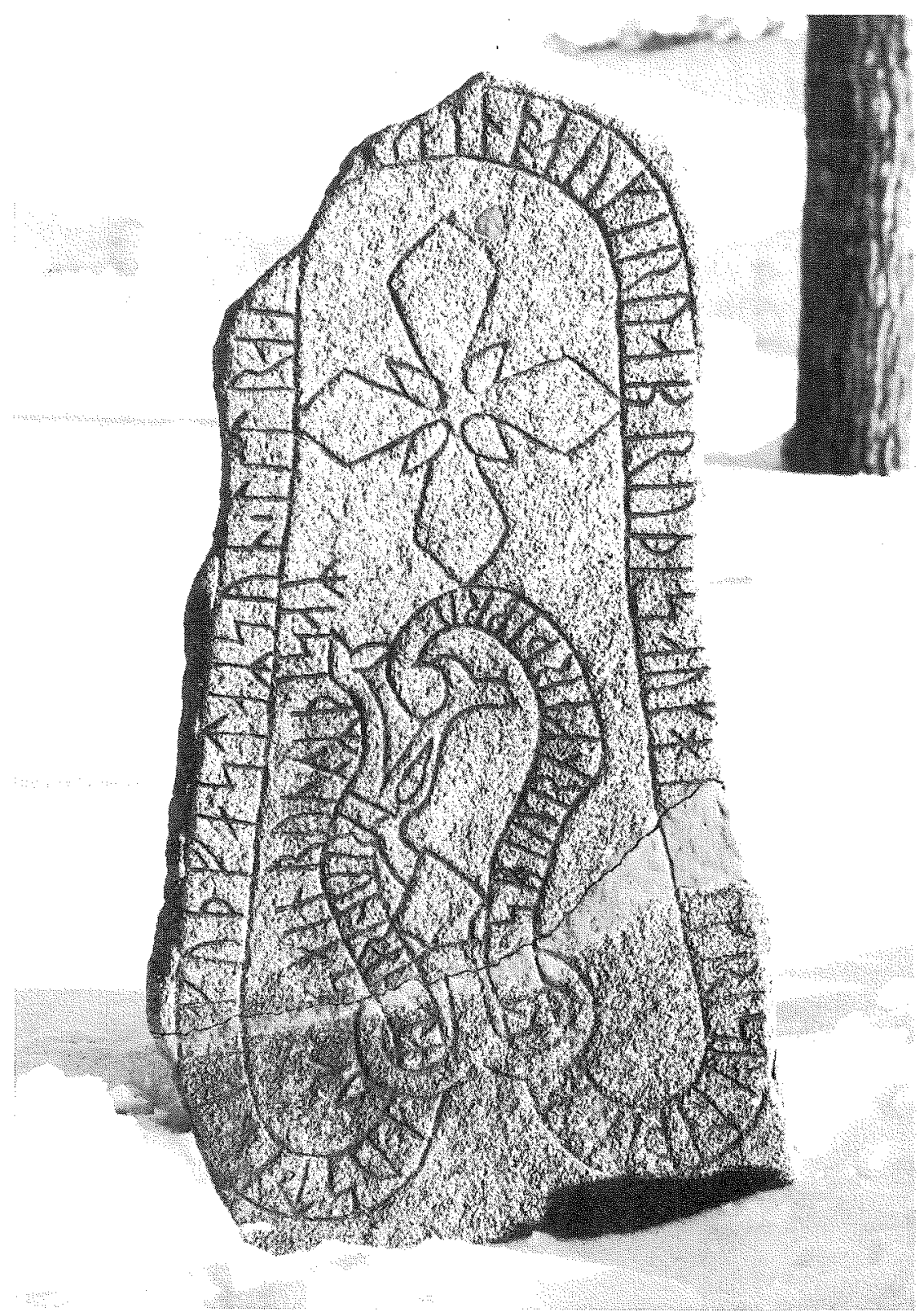

Fig. 4. The rune-stone from Frösön, Jämtland. The inscription says: austmąpr kupfastan sun . lit rai... ping aukirua bru bisauk h[an li]t kristna eątaląnt asbiurn kirbi bru triun raist auk tsain runąr bisan "Östman, son of Gudfast, erected this stone and made this bridge, and he christianizised Jämtland. Åsbjörn made the bridge. Tryn carved and Sten these runes". Cf. Jansson 1977, 119. 


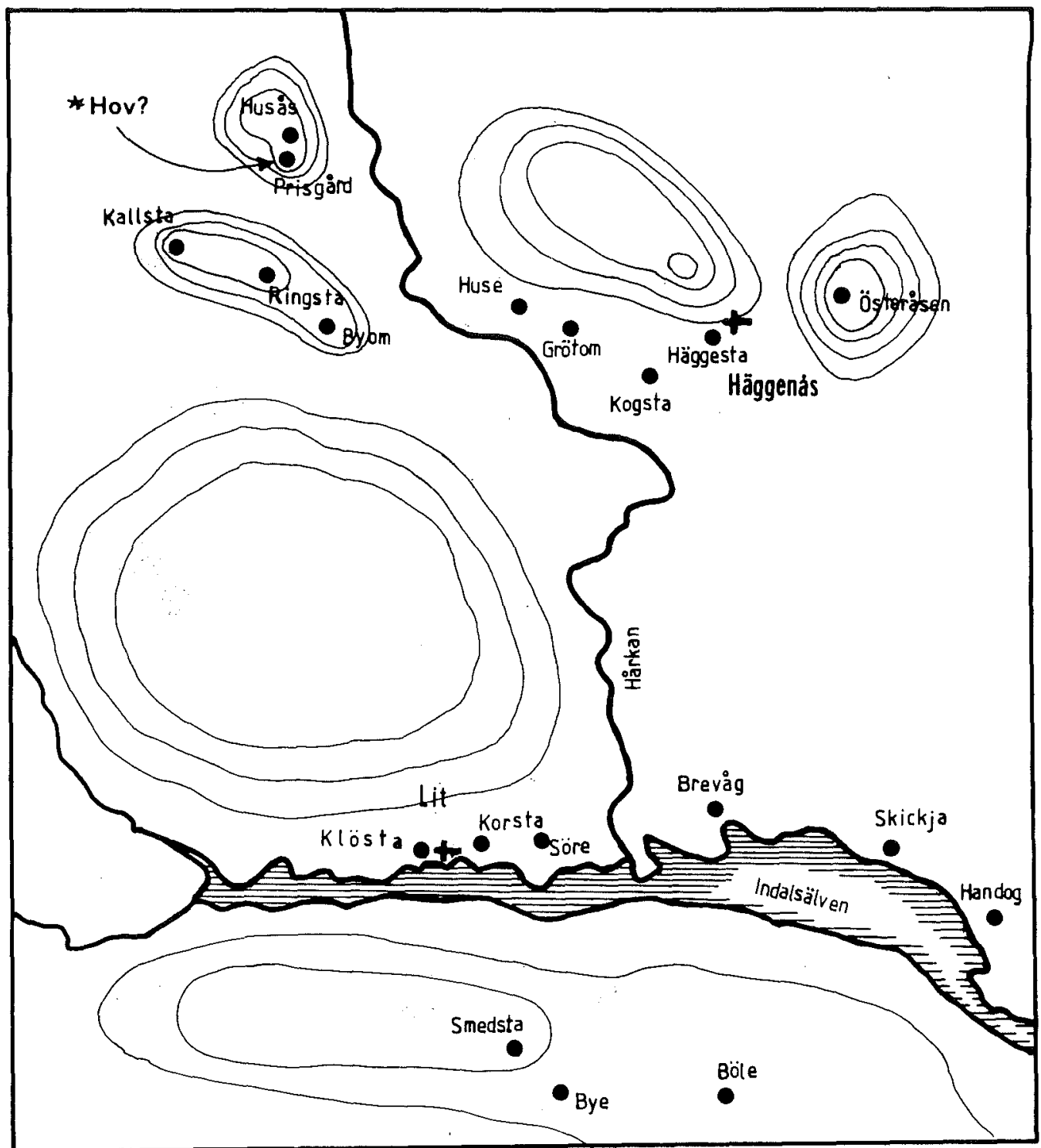

Fig. 5. The settlements in the parishes of Lit and Häggenås, Jämtland (cf. the text). 


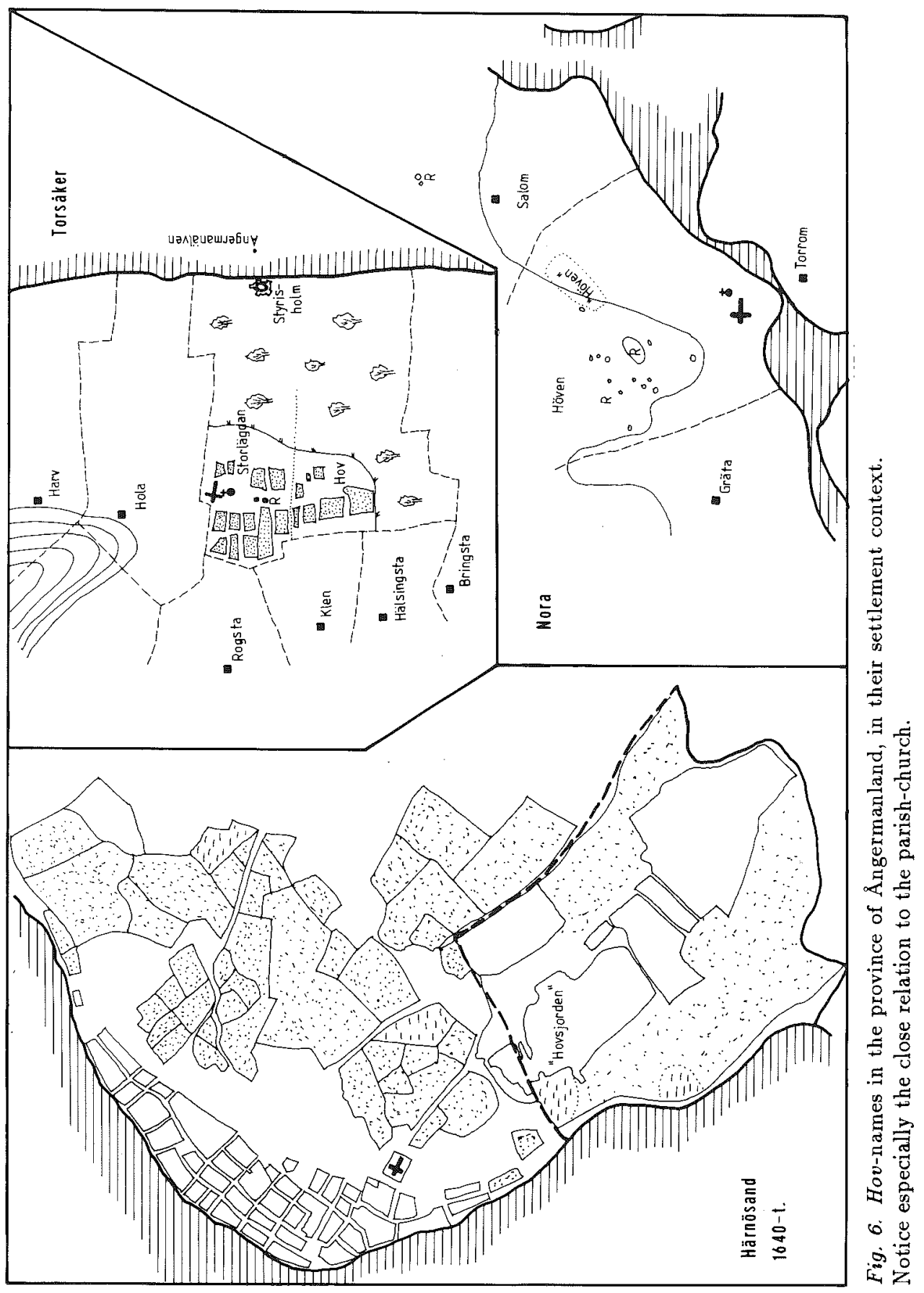


woodland. There seem to be no ancient monuments. A characteristic feature worth noticing is what is probably the most extensive system of hunting pits for elks in Sweden, found in the woods around the river Hårkan (See Selinge 1974; see Selinge 1976, 17 ff.). In this settlement site is to be found the northern, small settlement of Husås, with the two field-names Hovslägden and Hovsåkern. ${ }^{2}$

Place-names in Hov are furthermore found in the provinces of Angermanland, Medelpad and Hälsingland, although in a lesser number than in Jämtland. The hov-settlements in Angermanland, of which there are only two, ${ }^{3}$ have the same central situation in the parish as those in Jämtland (cf. fig. 6). Hov in the parish of Torsåker, Ångermanland, is the name of the church-village. We find here an interesting complex of names, bearing witness to some kind of cultic occupation, which may have been relevant to a wider area than just this parish. Here we find the name Hov. The name of the parish is furthermore Torsaiker, which may be assumed a priori to come from the fact that the first church was built on what may have been a cultic field (Swed. åker), sanctified to the pagan god Tor. As a parish-name one can thus assume an origin as a name of the church site. ${ }^{4}$ It is also worth noticing that a hamlet Harv (Harff 1535, RA ghj) is situated just north of Torsåkers church. As Allan Rostvik (Rostvik 1969) has shown, this name has a direct cognate in harg, which in at least some cases denoted a pagan cult site. In close relation we thus find three names Hov, Torsaiker and Harv which may bear witness to a pagan cult (see below).

The other hov-place in Angermanland is today incorporated in the town of Härnösand. This Hov settlement was obviously in ancient times situated on the island of Härnön (Bucht 1935, 7 f.) and it seems that the first church was erected on land belonging to Hov. The parish of Härnö was during medieval time an annexe to the parish of Säbrå. From older ordnance survey maps one can conclude where this Hov must have been located. A land called Hovsjorden, situated to the south and east of the church in the town, contained the two settlements Hov and Fagelsta. In the year 1586 the king granted three farms in Hov to what was then the newly founded town of Härnösand. Evidently Hov can be located just southeast of the church.

2 For a special interpretation of Husås and Huse see Hellberg 1984, $140 \mathrm{f}$.

3 Hov in the parish of Häggdånger is obviously a loan from Hov on Härnön (Bucht 1920, 4; Bucht 1935, 7; SOVn 1, 18), where the town of Härnösand is situated today, and $H o v$ in the parish of Anundsjö seem to be fairly young (Bucht 1920, 4; SOVn 4, 7). It is perhaps a loan from Hov in Torsåker?

4 For different kinds of parish-names, see Öberg 1979, 33. 
We may have to reckon with a third hov-name in Ångermanland, namely Höven (Hoffuom 1559, RA jb) in the parish of Nora. Today this is the name of the vicarage here. The name has been interpreted as a composition Hov-vin, but V. Jansson (Jansson 1951, 24) assumes that the name is more probably an inflected form, hovinu, of hov, an interpretation however, which T. Bucht (SOVn 1, $33 \mathrm{f}$.) does not seem to accept. Looking at the settlement situation, this Höven corresponds to the other two hov-places in this province. It seems possible to advance the hypothesis that the vicarage in the parish of Nora in older times had the name ${ }^{*} H o v$, a name that during the 16 th and 17th centuries became changed to Höven. Another Höven (Höffön 1535, RA ghj) is found in Angermanland, in the parish of Resele. This name has also been interpreted as an older ${ }^{*} H o v-v i n$, but T. Bucht (SOVn 2, 38f.) also mentions the possibility of this name being coined after the presumably older Höven in Nora parish.

In the province of Medelpad we also find two hov-names, Hov in the parish of Selanger and Hovid in the parish of Alnö (cf. fig. 7). The former is the name of a hamlet with a very central situation, just to the west of the church and the medieval royal estate of this province. The hamlet is situated on the Kungsnäs, an outcrop of land which in older times was situated in the bay of Selångersfjärden. Hovid, situated on the northernmost head of the island of Alnön, has older spellings which could allow one to assume the name to be an older hov-name. The site, ca. 4 kilometres north of Alnö church, on the very edge or head of the island, has led G. Bucht (Bucht 1920, $3 \mathrm{f}$.) to the suggestion that the name simply contains the $\mathrm{S}$ wedish word huvud 'head'. The topographical circumstances actually make such an interpretation plausible. Also worth noticing in this matter is the nearby name of Nacka, probably meaning 'neck'. It should be noted that we also find a $v i$-name on Alnön. One possibility is that Hov on Alnön could have been the collective cult centre for the districts, later parishes of Alnö, Skön and Timrå, a meeting place that was reached by water. The distance from the church, the occurrence of a vi-place in the vicinity and the location beside a hill makes a non-cultic meaning also possible for this name. Hovid must hence be regarded with some scepticism.

In the province of Hälsingland we find only two hov-names, i.e. in the parishes of Arbrå and Söderala (cf. fig. 8). They both have a very central situation in the Iron Age settlement. No land upheaval or small hill, which could be thought as being references for the names, is to be found in either case. Furthermore, these two hov- 


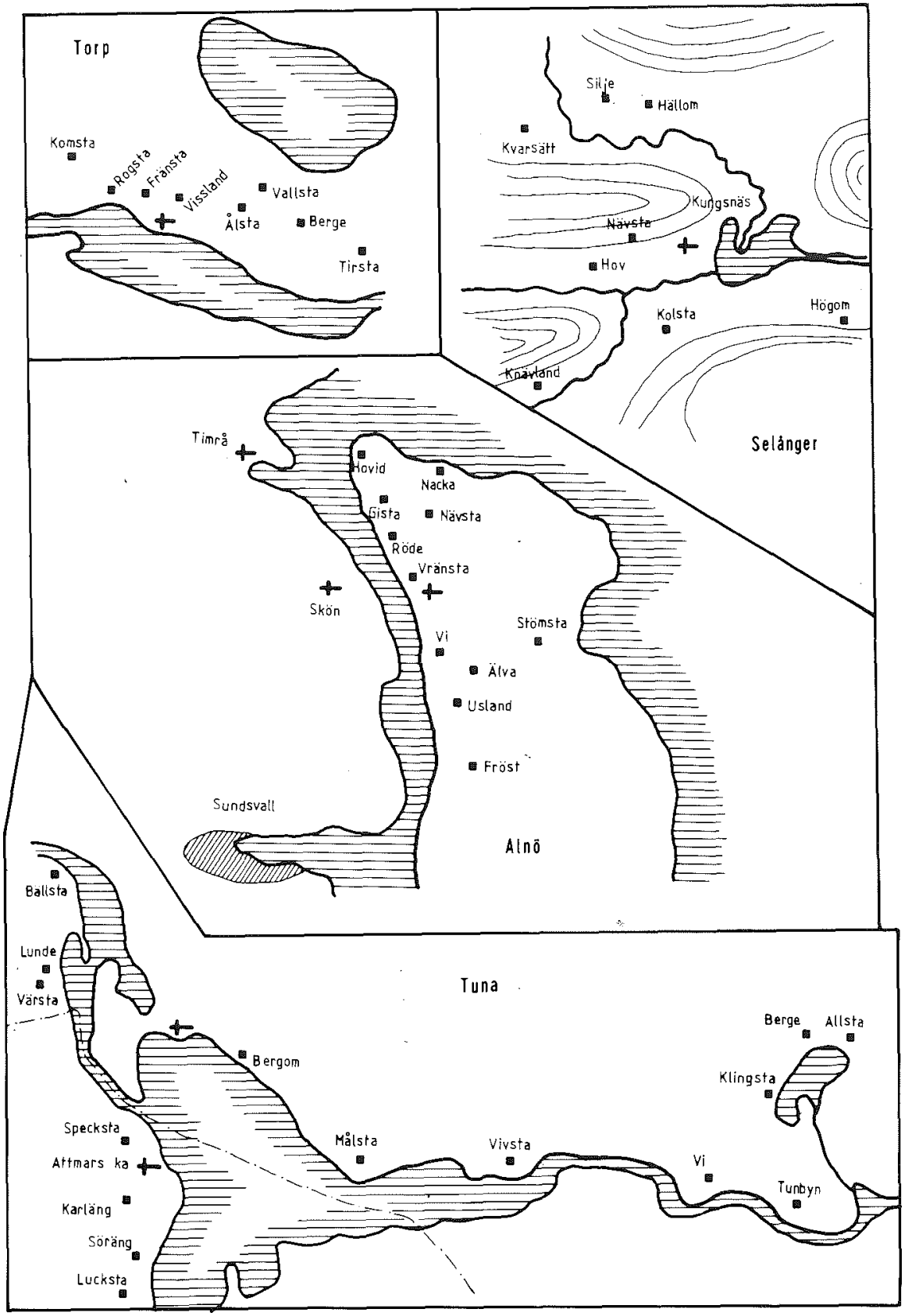

Fig. 7. Vi- and hov-names in the province of Medelpad, in their settlement context. Notice especially the close relation to the parish-church (except for Vi in Tuna). 


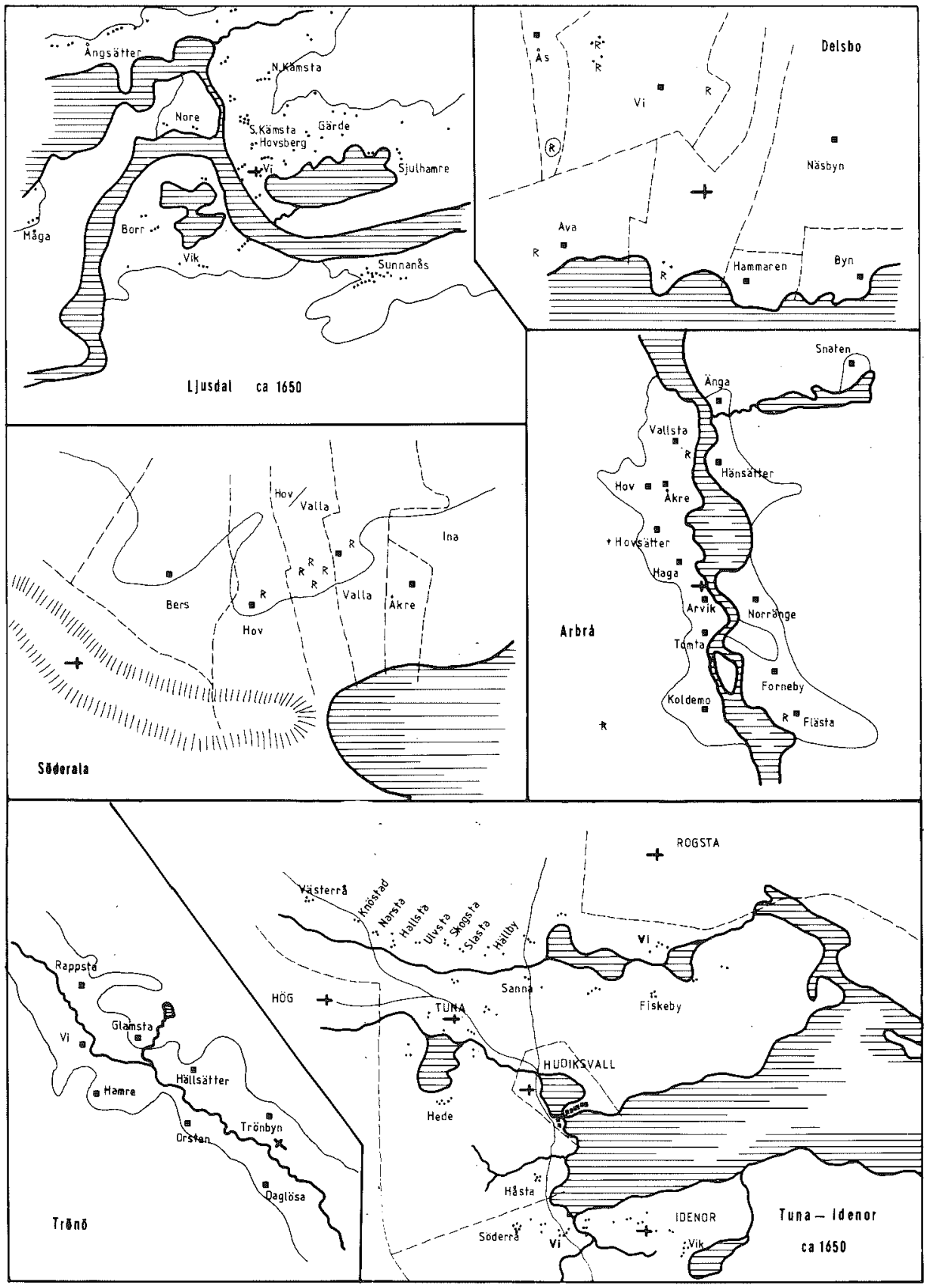

Fig. 8. Vi- and hov-names in the province of Hälsingland, in their settlement context. Notice especially the close relation to the parish-church (except for Arbrå, Trönö and Tuna). 
names are the only place-names in each parish indicative of cults. It therefore seems possible to understand these places as the two pagan cult site of the settlement districts. It is worth noticing that the adjacent village to Hov in Arbrå is Akre. This simplex Akre is found in several parishes in Hälsingland as the name of an extremely central hamlet, usually the neighbouring village to the church. An apparently plausible assumption is to regard this aker 'arable-land' as having in older times possessed some special function, maybe a parallel to Torsåker in Angermanland. Such an interpretation has already been proposed for several Åkers in central Sweden and elsewhere, villages with a very central situation in each settlement-district (See Lundberg \& Sperber 1911, 23, 26 f.; see Olsen 1915, 90, 98 ff., 205 ff.; see Lindquist 1918; see Brate 1918; see Wessén 1923, 10 ff., 19; see Hellberg 1986, 56). As the neighbouring hamlet to Hov in Söderala we find the hamlet Valla. This name may perhaps be seen in conjunction with some place-names $\operatorname{Vall}(a)$ in the neighbouring province to the south, Gästrikland, which all have a very central situation in each parish. The scholar Folke Hedblom (Hedblom 1958, 75 f.), our most distinguished scholar of place-names in the province of Gästrikland, writes that these vall-places may possibly have been "gathering places for profane and religious matters".

\section{LIST OF HOV-NAMES IN NORRLAND}

\section{Jämtland}

1. Hov, Hackås - [vid] hoffs kirkio 1408, JHD 1, 144.

2. Hov, Ås-i Hoff 1566, JR 1, 198.

3. Hov, Alsen - a hufui, in hufwi 1392, JHD 1, 124.

4. Hov, Norderö - i Hooff 1564, JR 1, 25.

5. Hov, Frösö - j hofui 1428, JHD 1, 194.

6. ?*Hov, Lit - cp. Hoffzlegde 1568, JR 2, 49.

Ångermanland

7. Hov, Torsåker - hăf 1527, SOVn 2, 59.

8. Hov, Härnösand - Hooff 1535, RA ghj.

9. Höven, Nora - Hoffuom 1559, RA jb.

10. ?Höven, Resele - Höffön 1535, RA ghj.

Medelpad

11. Hov, Selånger - i Hoffwj 1365, MÄU 22A; i hoff 1453, MÄU 57.

12. ? Hovid, Alnö - $\mathrm{i}$ hoff 1535 , RA ghj; hoff 1543 , RA jb; Hoffue 1562, RA jb.

Hälsingland

13. Hov, Arbrå - Hoff 1535, RA ghj.

14. Hov, Söderala - Hoff 1535 , RA ghj. 


\section{2. $\mathrm{Vi}$}

The other type of name - normally a simplex - denoting a pagan cult site is $V i$. The word vi has cognates in Swed. viga 'marry, sanctify' and Germ. Weihnachten 'the holy nights (Christmas)'. The word is obviously an old adjective, Protogerm. *wiha-, converted into a noun; cf. Goth. weihs 'holy' (Cf. Hellquist 1948, 1337; cf. Hellberg 1986, 47). This type of name has at least until now been fairly uncontroversial, in the respect that no alternative denotation to the cultic one has been put forward in Scandinavia. The Norrlandic Vi-names are mostly found in the provinces of Gästrikland and Hälsingland, but also have some scattered occurrences in the provinces to the north.

In Hälsingland the five $v i$-hamlets have a rather interesting distribution (cf. fig. 8). On the coast, in parishes such as Trönö and Tuna, one find a noticeable distance between the church and the hamlets with names based on vi. In the more inland parish of Delsbo the $V i$ hamlet is the neighbouring village to the church, while in the inland parish of Ljusdal the church is erected in the Vi hamlet. This situation has been interpreted as follows (cf. Jonzon 1973, 187): Christianity was first introduced into the coastal parishes of this province, and a tension between the two competing religions therefore led to the foundation of a new, Christian cult site - frequented at that time by some of the inhabitants of this district - at a safe distance from the old, pagan one. In inland areas on the other hand, where Christianity is assumed to have penetrated at a somewhat later date, the ground was better "cultivated" so that people may have converted to the new religion as the result of a commonly taken thing-decision and therefore without severe problems about building the church on the old pagan cult site. Whether these speculations really contain any substantial truth is very difficult to say. I myself am more inclined to explain this situation as a result of an adaptation to a new settlement situation in the parishes. Finally, however, we may conclude that beside these names we may also have to reckon with another vi-name in the parish of Forsa, which will be discussed below.

In the province of Medelpad we seem to have two, maybe three vinames (cf. fig. 7). Firstly $V i$ in the parish of Tuna. This hamlet is situated on the north side of a stream in the river Ljungan, just east of the lake Marmen. The neighbouring village to the east is Tunbyn, while the church in Tuna is situated some five kilometres to the northwest. The settlement site around Lake Marmen is somewhat difficult to interpret, which makes it hard to place the hamlet of $V i$ 
in a comprehensible settlement structure. ${ }^{5}$ Secondly, $V i$ on Alnön is not in any direct contact with the parish-church either. The hamlet is situated a kilometre or so to the south. Thirdly, we can probably with David Palm (Palm 1931, 8 f.) reconstruct another $* V i$ from a placename Vissland in the parish of Torp. This latter hamlet is situated just north of the church. A possible hypothesis is that the church has been erected on a settlement called *Vi. If this interpretation is correct, the old torp designation - which survives in the name of the parish - must be understood as the old name of a settlement-district (See Hellberg 1954, 133 ff.) One can not however exclude the possibility that the older name of the church-village in this case was Torp.

In the province of Jämtland we find only two vi-names, a simplex $V i$ in the parish of Näs and a lost ${ }^{\dagger}$ Ullvi in the parish of Hackas, both thus situated in the southern part of the province (cf. fig. 3). This + Ullvi has been reconstructed by Carl Lindberg (Lindberg 1933) from a fieldname Ullvi Lägd, found in ordnance survey documents from 1769 from the village of Sanne in Hackås. He furthermore connects this name with a "Sanvij", which is mentioned in a letter from 1478, and explains the latter form as having arisen to prevent confusion between this $v i$ and $V i$ in the neighbouring parish of Näs. It is worth noticing that in the parish of Hackas we find both a hov and a vi, and also that two vi-places are situated so close to each other as those in Näs and Hackås. Carl Lindberg (Lindberg 1933) and Nils Ahnlund (Ahnlund $1948,125)$ interpret this situation as a chronological difference in the sense that hov would be younger and therefore superimposed on an older vi. This could of course be the case, but the possibility should not be excluded that we have rather a difference in function or maybe one of cultural influence and not of time.

In the parish of Näs the church is situated in the hamlet of Oldberg (j Aalbergh 1529, DN 14, 674 or.; Alberga 1568 JR 2, 66) and is adjacent to the hamlet of $\mathrm{Vi}$. The name Oldberg, thus an older Alberg,

5 Notice the hamlet Vivsta (j wivestadhe $1460 \mathrm{MÄU} 62$; Wiwilstadha $1483 \mathrm{MÄU}$ 91), neighbour to the west to $V i$ in Tuna. The first element in this place-name is obviously Vivil, OWN. Vifill, a male personal name (Lind 1905-15, 1094 f.), but also an Old-Scandinavian term for a pagan priest (Hellberg 1979, 129; Müller 1968). Lars Hellberg (Hellberg 1979, 129; Hellberg 1986, 63) has persued the thesis that the OSwed. *vivil(l) 'pagan priest' is to be found in several Swedish place-names, and that names like Vivelsjö and Vivelsta are to be understood as kinds of heathen "vicarages". From this point of view, Vivsta in Tuna could very well qualify for interpretation as the pagan "vicarage", neighbour to $V i$ as it is. The possibility that the first element in this name is the well-established male name Vivil, Vifill must however also be considered in the future. Brink 1986, $58 \mathrm{f}$. 
is interesting but yet uninterpreted. It would be attractive to see here the remainder of a cultic element ${ }^{*} a l$, in this case in a variant * all (see below). Such an interpretation have been put forward for the place-name of $A$ lberg in the parish of Mora in Dalecarlia by Bror Lindén (Lindén 1954,68). An interpretation based on topographical conditions also seems to be possible.

\section{LIST OF VI-NAMES IN NORRLAND}

\section{Jämtland}

1. Vi, Näs - j wj 1439, JHD 1, 229.

2. †Ullvi, Hackås - cp. Ullvi Lägd 1769; Sanvij 1478.

Medelpad

3. Vi, Tuna - i wij 1363, MÄU 21.

4. $V i$, Alnö - i wy 1535 , RA ghj.

5. ?*Vi, Torp - cp. Vissland (i Wislandom 1417, MÄU 37).

\section{Hälsingland}

6. Vi, Ljusdal - vij $1542, \mathrm{RA} \mathrm{jb}$.

7. $V i$, Delsbo - i vi $14225 / 2$, RA p or.

8. Vi, Tuna - i Wij 1391, Liedgren 1981, 40.

9. Vi, Idenor - wij 1535, RA ghj.

10. Vi, Trönö - Vij 1535, RA ghj.

11. ?*Vi, Forsa - cp. Byberg < Viberg? (wiberg 1542, RA jb).

\subsection{An attempt to date the pagan cult sites in hov and $v i$}

I will also attempt to comment on the age of these pagan cult-names and cult sites, on the basis of the Norrland situation. On linguistic grounds we can see that the names ought to be of pre-Christian origin, from compounds with a pagan god's name as the first element. There is nothing in the Swedish linguistic material to suggest that these place-name elements were in use during medieval time. This gives us a terminus ante quem for the two elements hov and vi. Some nonlinguistic indications also give us grounds for establishing a terminus post quem. In the parishes of Söderala and especially Arbrå we have - according to archaeological evidence - had a settlement only from the later Iron Age; it is maybe possible to be more precise and say Viking Age. It is the same case in Ljusdal and Delsbo, where we have place-names containing vi.

In Hackås in Jämtland Carl Lindberg and Nils Ahnlund reckon that Ullvi is situated within such a settlement-situation - close to a hem-name - that vi can be regarded as belonging to an older 
period than hov, while Hov in this parish is surrounded by sta $(d)$ villages, which they obviously assume are datable to a somewhat later period (cf. fig. 3). This hypothesis is possible but speculative. On the archaeological and onomastic evidence such a hypothesis becomes utterly vague.

From these indications one may perhaps venture the conclusion that at least in Norrland the cult-indicating elements $v i$ and hov were in use during the later Iron Age. These cult sites would thus have been the direct predecessors to the new, Christian cult-habitations, the churches.

\section{Theoforic place-names}

Theoforic place-names are not so numerous in Norrland. ${ }^{6}$ But these few are linked with important information regarding the pagan gods that were worshipped in the north (fig. 9). The name of the god Frö seems to be found in Frösten (< Frøstuna), the church-hamlet in Jättendal, Hälsingland and in Frösö in Jämtland, while the name of the pagan goddess Fröja seems to be found in the parish-name Frötuna (j ffrøtwnom 1513, MÄU 136) in Medelpad. Fröja was also previously assumed in several Fröland designations in Norrland, but later research has generally chosen not to regard these as theoforic names (see below). Tor is represented in the two parish-names Torsaker (De thorsakir 1314, DS 3, 148) in Gästrikland and Torsåker (De Thorsakir $1314, \mathrm{DS} 3,150)$ in Angermanland, and probably in a lost ${ }^{\dagger}$ Torsåker in Torp, Medelpad, which was situated close to the church. ${ }^{7}$ The name of the goddess ${ }^{*} N$ järd seems to be found in the island-name Norderön, which, like Frösön, is situated in the great lake Storsjön in Jämtland. The interrelationship of these two names has generally been assumed, bearing witness to a fertility cult where a couple of pagan gods Frö and *Njärd were worshipped together. This is the traditional interpretation of these names and may perhaps be correct (Wessén 1923,9 ). In that case this is probably the only example in

\footnotetext{
6 One can compare the Norrland theoforic place-names with those, for example, in the province of Uppland, which according to Lars Hellberg 1986, 54 number more than 50 .

7 For the latter name, see Flemström 1960, 14. This place-name is not found in medieval letters or 16 th century cadastrals. It has probably been observed in a passage in Hülphers (Hülphers 1771, 52) which says (in translation): "A place west of the church is still called Torsakker", cf. Nordlander 1903, 234. While this placename is somewhat doubtful, it is not found on the map of theoforic place-names in Norrland (fig. 9).
} 


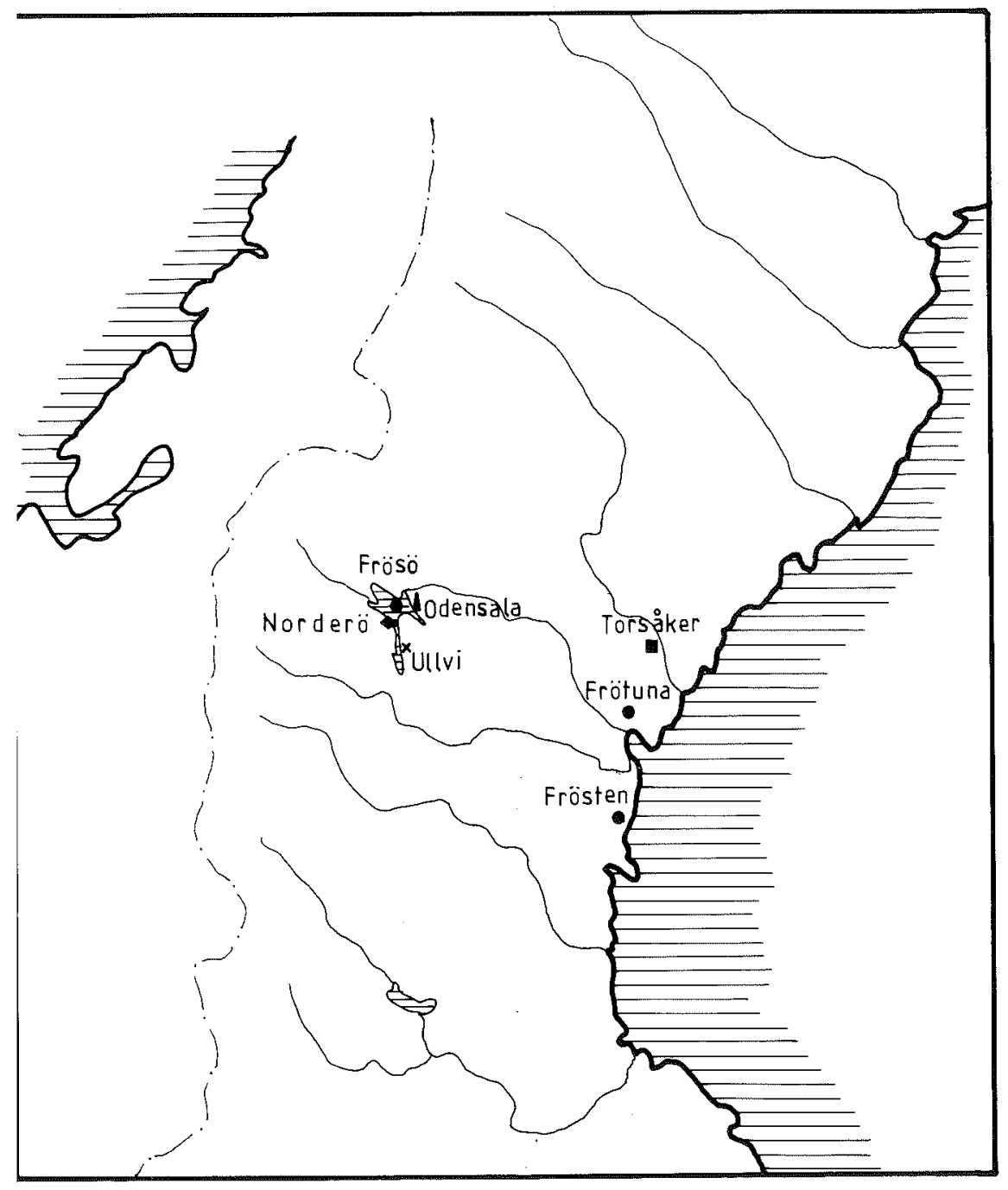

Fig. 9. The theoforic place-names in Norrland, indicating a worship of the heathen gods Ull, Frö, Tor and Oden, and the goddesses *Njärd and Fröja. 
Norrland of such a fertility cult, where two gods can be distinguished in two geographically adjacent place-names. These types of name-pairs are usually found in the provinces of Östergötland and Uppland (Cf. Wessén 1921-22; cf. Wessén 1923, 8 ff.; cf. Hellberg 1986, 67). The name of the god Ull may only have a single occurrence in Norrland, i.e. in the nowadays lost ${ }^{\dagger}$ Ullvi in Hackås in Jämtland. There is also a single occurrence of the name of the god Oden in Norrland, and this is in Odensala, today a part of the town Östersund in Jämtland. The latter element in this name has been suggested to contain a word al or sal. Most probably it is a compound with the latter.

Beside these theoforic place-names several place-names have earlier been assumed to contain the name of a god or goddess. These names have been given secular interpretations in later research. Such an example is the parish-name Ullänger in Angermanland, a name which in earlier times was assumed to contain the name of the pagan god Ull as the first compound. Today it is commoner to see here an older river-name, maybe containing a stem *ull-, with a cognate in the Swedish verb välla (SOVn 1, 80). In the same way Ullberg (vllebergghe $1472 \mathrm{MÄU} 73$ ) in Njurunda, Medelpad, has been given a secular interpretation (Cf. Palm 1944, 39; cf. Flemström 1960, 13 f.). There is nothing from a linguistic point of view, however, to prevent an interpretation based on the pagan god Ull, which has been the opinion by some older scholars (See Nordlander 1903, 243; see Löfgren 1922, 95). The name Fröland is found in many places in Norrland. These have also earlier been understood as containing the name of the goddess Fröja. This interpretation must also in future be regarded as possible, but today scholars seem to prefer to see a word Swed. adj. frö $(d)$, denoting good growth on land (See SOVn 1, 69; see Flemström 1960, 13; see Brink 1984b, 67). The same meaning has been seen in Frök (Ffröck 1542, RA jb; < *Frø-aker?) in Nora, Ångermanland (SOVn 1, 31). Fröstland (fröslunda $1500 \mathrm{MÄU} 117$; ffreslwndh 1519 MÄU 143; ffrøsland $1520 \mathrm{MÄU} 146$ ), in Bjärtrå in Angermanland is also of interest. The two oldest spellings actually point towards an older compound *Fröslunda, which in this case has left the track to become Frös $(t) l a n d$. It is however uncertain how much one can rely on these two oldest spellings. Fröstland is situated some distance west of the church in Bjärtrå, surrounded by several old villages. The name must been regarded as a possible cultic name. ${ }^{8}$ To this group of elusive

8 T. Bucht in SOVn 1, 6, who did not have access to the two oldest spellings for his investigation and interpretation of this place-name, gives an alternative, secular 
names one may perhaps also add Frea (Fröal 1546, RA jb; SOVn 2, 15 ) in Dal in Ångermanland and Fröst (ffrössetther 1535, RA ghj) on Alnön in Medelpad, which have both been thought to contain the name of the pagan god Frö. ${ }^{9}$ In Ljusdal, Hälsingland, there is a small hamlet with the name Onsäng (onsänge 1542, RA jb; Ondensänge 1557, RA tl) which has traditionally been assumed to contain the name of the pagan god Oden. Of course this possibility cannot be excluded, but in a name containing - äng - an element which in Hälsingland seems to be of medieval or later origin in settlement-names - the name of a pagan god is not really to be expected. Most probably one can reject Onsäng as an old cultic name (Brink 1984b, 91).

\section{Other possible cult elements}

\section{1. lund}

Apart from these theoforic place-names and the vi- and hov-names, one must probably include among the old cultic place-names one or two place-names of other origin within the Norrland name-material. In these cases, however, it is difficult to be categorical; one can only suggest the possibility and present arguments which can support such an interpretation. One type of names where we remain in uncertainty are the lund-names. Obviously lund can denote some kind of cultic grove as a place-name element, as may be concluded from middleSwedish place-names. But a secular meaning is certified as well. Perhaps the name of the hamlet Lunde in Jättendal, Hälsingland, is such a cultical lund-name, as has been suggested by Lars Hellberg (Hellberg 1984, 138). In the province of Jämtland it seems that the name Lunderänget, denoting a neighbouring farm to the church on Norderön and to the hamlet $H o v$, may possibly have a cultic origin. Bertil Flemström (Flemström 1983, 41 f.) keeps the possibility open, furthermore, that the hamlet Lund in Hällesjö may also have a cultic origin. Lunde in Tuna, Medelpad, seems promising in this sense as well. In this hamlet there are unusually many ancient monuments. Besides these, there are several lund-names in Norrland where only a thorough analysis can give us an hint of whether lund may have a cultic origin or not.

interpretation.

9 For a profane interpretation of the latter name, see Flemström 1960, 13 (< adj. frö(d) 'luxuriant'). 


\section{2. stav}

Just like lund, the place-name element stav may be demonstrated as having a cultic origin in some cases. In these cases stav probably denoted some kind of staff, a symbol in the pagan cult (see below). The place-name element stav also has secular meanings, such as a border pole, a fence-construction, maybe a runestone etc. (See Palm 1940; see Ståhl 1980-82, 79 ff.; see Olsson 1976). Where Norrland is concerned, I find at least one case interesting to consider, namely Stavaiker in Forsa, Hälsingland, which I will comment on in greater detail.

\subsubsection{A reconstructed pagan cult centre ${ }^{*} V i$-Stavåker}

In this parish, Forsa, the small hamlet of Stavaiker is situated on the north side of the small lake of Funstasjön (fig. 10). A rather rich Iron Age settlement was obviously grouped around this lake. Of vital interest in this context is the immediately adjacent hamlet of Byberg (Bibergha 1535, RA ghj; i wiberg 1542, RA jb; wiberg 1543, RA jb; wyberg $1544, \mathrm{RA} \mathrm{jb}$; byberg 1546 , RA jb; wibergh 1549, RA jb; Byiebergh 1569, RA $\mathrm{jb}$ ). Such a name, from a linguistic point of view, gives a rather strange impression. ${ }^{10}$ As I have demonstrated in another paper (Brink 1988), this Byberg seems to be an older placename, Viberg, indicating a lost ${ }^{*} V i$, which ought to have been located in the vicinity of Stavaker and Byberg. This name ${ }^{*} V i$ - which may thus presumably have been the name of a cult site - has never been transferred to denote a settlement and thus preserved to the present day. The name would however be found in Byberg indirectly.

If this hypothesis can be proved correct, it seems plausible to interpret Stavaiker as originally possessing a cultic meaning. Maybe we have had here a kind of cult field, beside the pagan cult site with the name *Vi, where staffs - "stavar" - of some kind were erected, perhaps some kind of male fertility symbols or tree staffs erected over the deceased, of the kind mentioned by Ibn Fadlan when he met "rus" in $922 .{ }^{11}$ It should also be mentioned that there is a grave-field in Stavåker.

10 One must of course entertain the possibility that Byberg is an older *vidh Bargh, containing a preposition vid 'at, by, beside', but the occurrence of the neighbouring Stavaker inclines me to another interpretation.

11 Two interesting place-names in this connection are Stävje, a hamlet and a parish in Torna hd (Staføghe 1267-99, LDLV, 168 or.; in Stæwøghe 1349, DS 6, 1, 4502 or.) and a hamlet in the parish of Räng, Skytts hd (in stæwøgh $\varnothing 1303$, DS 2, 1385 or.; in Stæff $\varnothing$ ghe 1352, DS 6, 1, 4801 RELu), both in Scania. The names contains - h $\varnothing g h$ (most probably) 'tumulus, gravemound' and stav 'staff, pole' (in sing. or plur.) 


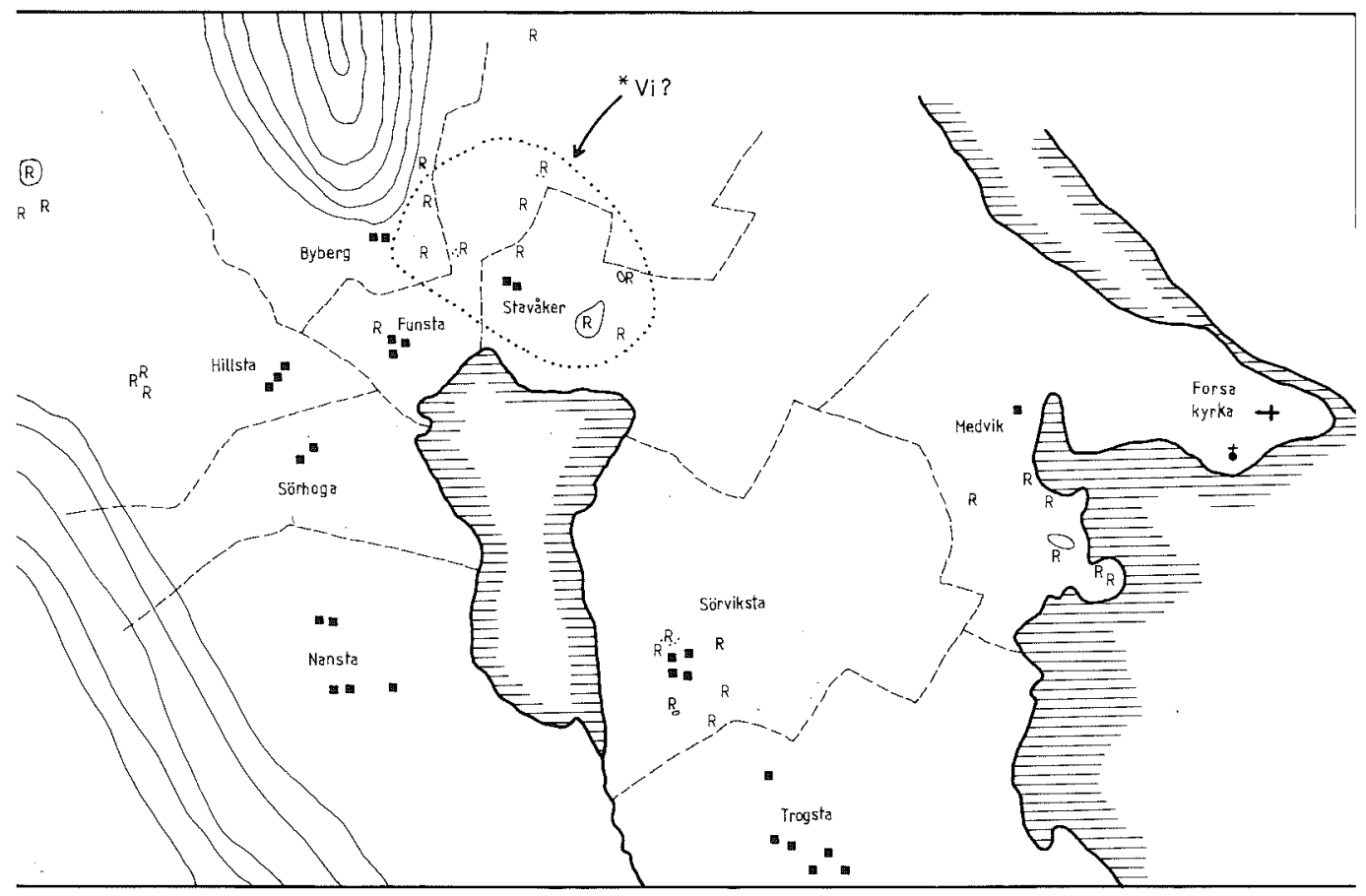

Fig. 10. An attempt to reconstruct a pagan cult site ${ }^{*} V i$ in the parish of Forsa, Hälsingland (cf. the text).

\section{3. helig}

A place-name Helgum $\left(<{ }^{*}\right.$ Helgha-hem) is found three times in the province of Ångermanland, i.e. in the parishes of Säbrå, Gudmundrå and Helgum, and in Medelpad in the parish of Njurunda. The first element in these names contains the word helig 'holy'. The question is whether the meaning has been profane or sacred (Cf. Calissendorff $1964,147 \mathrm{f}$.). This we will obviously never know, but must describe these place-names as potential cult names. An interesting place-

(Pamp 1983, 40). Obviously a staft has been erected on a prominent tumulus. Ibn Fadlan mentions that "rus" worshiped a staff which had the name of the deceased carved into the tree-pole. Maybe the kind of staffs that Stävje indicates can be seen in the light of what Ibn Fadlan describes:

And then they made on that site where the ship - which was pulled up from the river - had been, something, that looks like a round mound, erected a staff or wood in the centre and wrote thereafter the name of the [deceased] man and the name of the king of Rus.

(Vikingerne 1981, 59). Here translated from the Danish. 
name in this connection is the nature-name, Hellberg, in the parish of Järvsö, Hälsingland. It nowadays denotes a hill, containing fine sandy sediments, situated just beside the small island where the church stands (fig. 11; cf. Brink 1984b, 38). The first scholar to pay any attention to this place-name was J. Hanzén (Hanzén 1941, 15 ff.), who suggests that the name contains the word helig 'holy' and that this alluded to some cultic activity.

Another interesting place-name containing the word helig 'holy' is the name of the ancient island of Helgo..$^{12}$ During the late Iron Age and early Middle Ages Helgö denoted a small island, which had a completly protected situation and was fairly accessible from the large settlement-centres of Tuna, Hög and Rogsta (fig. 12). It is fascinating to try to explain Helgö in terms of the settlement situation, trade, naval organization etc., but I shall leave the subject for the moment, merely asserting that the name contains the word helig which can have a sacred meaning as well as a profane one, such as peace and protection during matters of council, trade etc.

\section{4. *al?}

A separate problem of its own is formed by the place-name element al. Such a cultic element has since long been recognized in Scandinavian place-names, with an assumed close cognate in Goth. alhs 'temple'. The most well-known place-names mentioned in this relation are Motala, Götala, Fröjel etc. The Norrland names which have been mentioned in this connection are the medieval district-name of Alir and the parish-names Norrala and Söderala, all in Hälsingland. Also Odensala in Jämtland and Frea (Fröal 1546, RA jb) in Ångermanland have sometimes been mentioned in this respect. This connection between the place-name element $a l$ and the Goth. alhs 'temple' has been reiterated by generations of scholars during this century, but without any real research into the matter. From a linguistic point of view it has also been proposed that a variant form *ål occurred (e.g. Lindén 1954,68).

In my work with the place-names of Hälsingland I felt impelled to examine the validity of the cherished hypothesis that we have had a cultic place-name element ${ }^{*}$ al in Scandinavia. To be able to make some decision on this matter I have gone through all the relevant Scandinavian material and made some forays into northern Europe.

12 See also the description by Calissendorff $1964,147 \mathrm{f}$. 


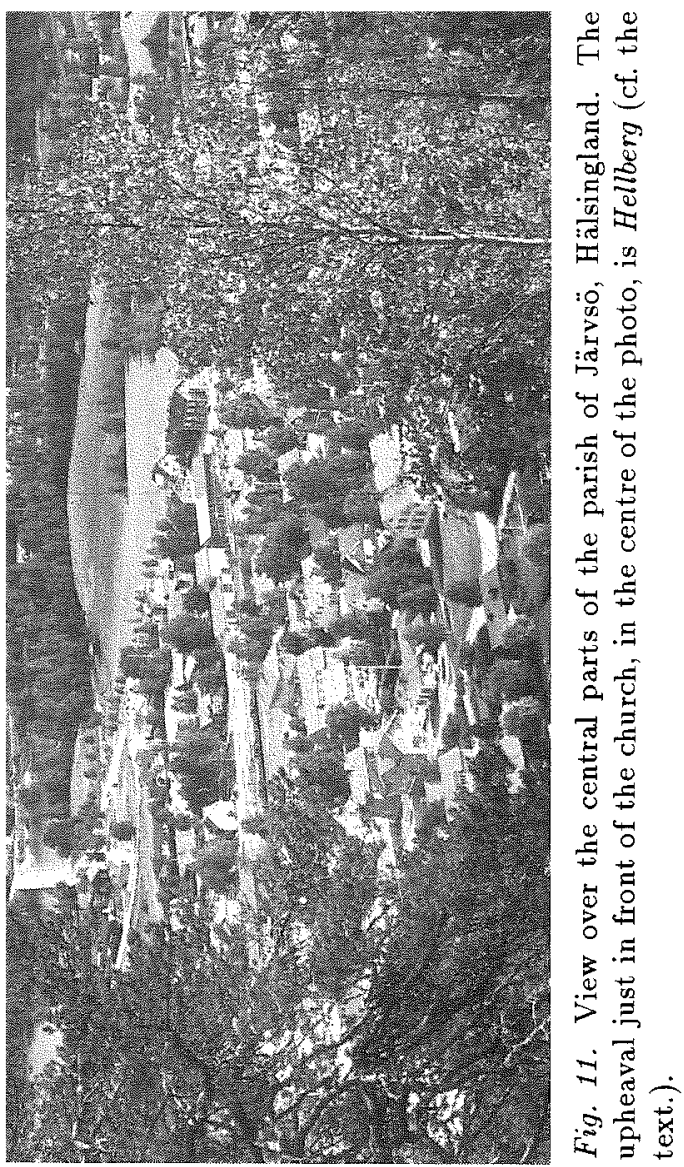




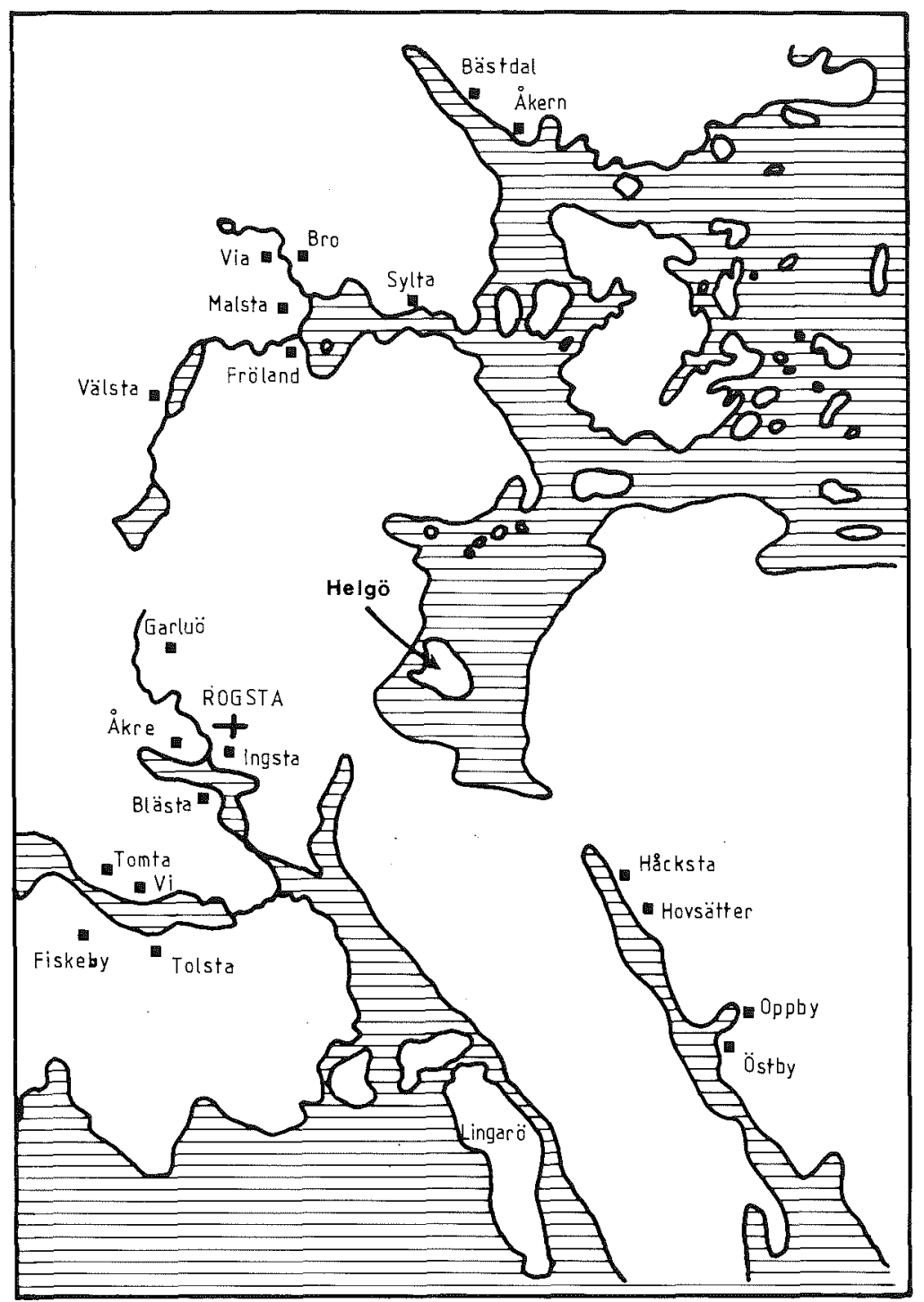

Fig. 12. Helgö in Hälsingland. The shore-line on the map is 10 metres above todays sea-level, corresponding to ca. Late Iron Age.

I hope I will be able to present this research in a complete work not anticipated here, but one result may be that there actually can be doubt as to whether a cultic element ${ }^{*} a l$ has existed in Scandinavia. If, however, an element ${ }^{*} a l$, corresponding to Goth. alhs, has existed in Scandinavia, there may be no need to explain this in terms of 
a cultic meaning. Furthermore, in most cases where scholars have reckoned with this supposed cultic *al, it is possible to consider other etymologies than the established one. I have done so with the placenames from Hälsingland and think I have found plausible alternative etymologies. Although I am not at this stage ready to reject the cultic element ${ }^{*} a l$ in Scandinavia, it may be strongly doubted in my opinion whether Norrala and Söderala have anything to do with pagan cult activities.

\section{5. harg, horg}

The place-name element harg, OWN horgr, has in recent years been discussed quite comprehensively. The old view was that harg, horg, with an original meaning 'heap of stones, rock', gained a secondary meaning 'cult site' from the habit of using heaps of stones as pagan sacrificial altars. Allan Rostvik (Rostvik 1967) pursues the thesis that this hypothesis is wrong and that the cultic meaning is young, introduced during the medieval period from the literature, especially when clergymen translated the Bible and hence used the profane word harg, horg to denote biblical terms such as sacrificial hills etc. In mine and others opinion this is pushing things too far (See e.g. Hellberg 1986, 48). It seems that harg, horg has had a pronounced meaning of 'cult site, building for religious purposes', both in old West Nordic literature and in place-names, besides the profane one.

Two Norrland names containing the West Nordic variant horg are Hurjom (Horgem 1542, RA jb) in Överlännäs, Ångermanland and Horga (horghum 1324 26/3 RA p or.) in Hanebo, Hälsingland, both obviously of non-sacred origin, denoting stony terrain and big rocks (Rostvik 1967, 14 f.).

A variant form of harg, horg, as A. Rostvik (Rostvik 1969) has shown, is harv, showing an alternation $r g h \sim r w$. Four harv-names are found in Norrland: Harv (i Harffs 1542, RA jb) in Forsa, Hälsingland, Harv (i Harfue 1451 15/3, UUB p or.) in Attmar, Medelpad, Harvom (Harfföm 1535, RA ghj) in Indal, Medelpad and Harv (Harff 1535, RA ghj) in Torsåker, Angermanland (See Rostvik 1969, 75 f.). These may all contain the profane meaning of 'stony terrain, rocks etc.', but at least for Harv in Torsåker the lack of stones in the terrain and the situation near Hov and the church in Torsaker makes a cultic interpretation interesting (cf. fig. 6). 


\section{The place-names of the Christian cult centres}

Until now, I have dealt with the names of pagan cult sites, but the names of Christian cult centres are of course also of great interest. The latter are now normally the names of parishes. In studying these parish-names from a typological point of view, we can obtain interesting information. A parish-name such as Torsåker obviously tells us that we have a continuity of cult site. This simple statement ought to make it possible to draw some conclusions about the conversion in this parish. The site was furthermore obviously found suitable as a gathering place by the clergymen of the church, too. In some cases it seems that the church acquired a different site to the pagan centre for cult and other gathering purposes, a new site probably regarded as more suitable for the medieval settlement situation. This is probably the case in the parish of Arbrå, Hälsingland, where the church has been built some kilometres south of what obviously has been the old pagan centre in this district at Hov and Akre (see fig. 8).

A conclusion from studying the Norrlandic parish-names is that, in contrast to parish-names from central and southern Sweden, these are far more often originally district-names. Another rather larger number of parish-names in Norrland are those which have an origin as the name of the place where the church was built, e.g. Forsa, Alfta and Bollnäs in Hälsingland, Torsåker in Ångermanland and Brunflo in Jämtland. In southern parts of the country we nearly always find that the parish has taken the name from the hamlet or farm where the church was built. One may thus wonder why we do not find parishnames such as ${ }^{*} V i$ parish or ${ }^{*} H o v$ parish in Norrland, i.e. where the parish has taken the name from the hamlet or farm were the church was erected. ${ }^{13}$ There must therefore have been some difference in the settlement structure and probably also in the territorial division of the areas when the church began the division into parishes during the early medieval period.

A conclusion from this is that there is no obvious comparison between parish-names in Norrland and those we find further south in Sweden. There is instead a far more obvious parallel between the former and the older district "härad" found in Götaland. The latter names normally have an origin as a district-name or a name from the gathering- and thing-place for the "härad" (cf. Andersson 1965). In the "härad" division advantage was taken of the old settlement groupings that existed, but these was normally far too large for a

13 One exception is however Torsåker in Angermanland (see above). 
parish. In Norrland however, the settlement situation and the lack of older divisions such as "härad" probably made it natural for the church to use the old settlement groupings - which often had natural borders - in its new parish-division. This is why we find old districtnames and names of probable gathering- and thing-places in Norrland parish-names.

During the last couple of years the department of onomastics in Uppsala has made some special studies of parish-names. ${ }^{14}$ These place-names can probably provide further information than what is known so far. By trying to ascertain what these names denoted at the actual establishment of the parish - whether a district, hamlet, gathering-site, or whether the parish-name was a new construction or simply the name of the church - we gain information about old gathering-sites, districts etc. A simple over-view of the parish-names of Sweden shows us, for example, that in Götaland nearly all parishnames are old hamlet or farm-names, whereas many of the parishnames of Norrland are old district-names. This fact can tell us that the churces in Götaland generally have an origin as private-churches; we furthermore obtain an interesting picture of different old districts in the provinces of Norrland, districts which ought to have a pagan origin and can hence be assumed to have had a pagan gathering and cult site. This gives us a foundation to stand upon for further analyses. I myself have made a special study of the situation in the province of Hälsingland and am about to present the results shortly. I believe that from the parish-names some prehistoric districts can be reconstructed and in that context more or less reliable gathering sites for cultic or legal matters can be established. In this connection, parish-names originating in the name of the church site are of utmost interest.

\section{Concluding remarks}

This paper has been an attempt to present the positive evidence we possess of pagan cult in Norrland and to point out Norrland cult sites. I hope that an overview of this kind can stimulate fresh research which can expand our knowledge in this field; in this respect, the present paper has been less obviously problem-solving than - hopefully research-evoking or even research-provoking. It is obvious that the

\footnotetext{
14 E. g. Andersson 1962; Andersson 1963; Wahlberg 1975; Falck-Kjällquist \& Strandberg \& Wahlberg 1976: Öberg 1979; Lagman 1981: Andersson \& Göransson 1982, 5 f.; Andersson 1984; Andersson 1987; for the present Brink 1984b, 30 ff.
} 
paper is in no way complete or comprehensive in this matter. It is above all the more easily tangible settlement-names which I have debated. For further research one can specially recommend the study of place-name records and ordnance survey maps and documents for the possibility of locating settlement-districts, old centres and gatheringplaces - where normally but not always the church has been built and other potential sites in this context, to gain new information on the subject. Such investigations may probably lead to new indications of a pagan cult. This is indicated above, where reconstructed cult sites has been demonstrated from evidence mentioned here, i.e. ${ }^{\dagger}$ Ullvi in Hackås, ${ }^{\dagger}$ Hov in Lit, ${ }^{\dagger} \mathrm{Vi}$ in Forsa etc.

\section{Bibliography}

Abrreviations

Goth. Gothic

hd Swed. härad, a district

or. letter in original

OSwed. Old-Swedish

OWN Old-West-Nordic

RELu Registrum ecclesie Lundensis, from 1494, RA

Stockholm

UNPUBLISHED SOURCES AND LITERATURE

RA Riksarkivet, Stockholm

ghj Gärder och hjälper; a tax from 1535

jb Tax cadastrals

p Parchment letter

tl Tithe list

Uppsala

UUB Uppsala Universitetsbibliotek

p Parchment letter 


\section{PUBLISHED SOURCES AND LITERATURE}

Ahnlund, N. 1948. Jämtlands och Härjedalens historia [1]. Stockholm.

Andersson, Th. 1962. Det östgötska sockennamnet Kumla. Ortnamnssällskapets $i$ Uppsala årsskrift. Uppsala.

- 1963. Sockennamnen Hedheskirkia 'Heda' och Røskirkia 'Rök'. Namn och bygd 51. Uppsala.

- 1965. Svenska häradsnamn. (Nomina Germanica 14.) Uppsala.

- 1984. Gammal territoriell indelning i ortnamnsbelysning. (Kulturhistorisk rapport 15. Länstyrelsen i Göteborgs och Bohus län.) Göteborg.

- 1986. Germanisch Hof-Hügel, Hof, Heiligtum. Sprache und Recht. Hrsg. von K. Hauck et al. Berlin.

- 1987. Olika typer av sockennamn. Klassiska problem inom finlandssvensk ortnamnsforskning. (Studier i nordisk filologi 67.) Helsingfors.

Andersson, Th. \& Göransson, S. 1982. Forskning om äldre territoriell indelning i Sverige. Bebyggelsehistorisk tidskrift 4. Stockholm.

Brate, E. 1918. Aker och Tuna. Fornvännen 13. Stockholm.

Brink, S. 1984a. Ortnamn som källa i historisk forskning. Fornvännen 79. Stockholm.

- 1984b. Ortnamn i Hälsingland. Stockholm.

- 1986. Personnamn i de nordskandinaviska staðir-namnens förleder. Personnamn i stadnamn. [Ed. by] J. Sandnes \& O. Stemshaug. (NORNArapporter 33.) Trondheim.

- 1988. Ett försök till rekonstruktion av en förkristen kultplats. Ingemar Olsson 25 augusti 1988. (MINS 28.) Stockholm.

Bucht, G. 1920. Hedniska kultorter $i$ mellersta Norrland. Härnösand.

- 1923. Kristendomens införande i Norrland. Från Adalar och Fjäll. Härnösands stifts julbok. Härnösand.

- 1935. Härnösánds historia 1. Härnösand.

Calissendorff, K. 1964. Helgö. Namn och bygd 52. Uppsala.

DN Diplomatarium Norvegicum 1-. $1847 \mathrm{ff}$. Christiania.

DS Diplomatarium Suecanum 1-. 1829 ff. Stockholm.

Falck-Kjällquist, B. \& Strandberg, S. \& Wahlberg, M. 1976. Sockennamn. Ortnamn och samhälle. [Ed. by] V. Dalberg et al. (NORNA-rapporter 10.) Uppsala.

Flemström, B. 1960. Ortnamn i Medelpad. Medelpad - drag ur bygdens historia. Sundsvall.

- 1983. Ortnamn i Jämtland. Stockholm.

Friesen, O. v. 1928. Runorna i Sverige. (Föreningen Urds skrifter 4.) Uppsala.

Hanzén, J. J:son 1941. Järvsö prästgård, dess hus och herrar under århundraden. Ljusdal.

Hedblom, F. 1958. Gästriklands äldre bebyggelsenamn. Från Gästrikland 1957-58. Gävle.

Hellberg, L. 1954. Studier i de nordiska torp-namnens kronologi. Namn och bygd 42. Uppsala. 
Hellberg, L. 1979. Forn-Kalmar. Kalmar stads historia 1. Kalmar.

- 1984. Svetjud och Norrlanden. Florilegium Nordicum. (Umeå Studies in the Humanities 61.) Umeå.

- 1986. Hedendomens spår i uppländska ortnamn. Ortnamnssällskapets $i$ Uppsala årsskrift. Uppsala.

Hellquist, E. 1948. Svensk etymologisk ordbok. [3. uppl.] Lund.

Hülphers, A. A. 1771. Samlingar til en Beskrifning ofwer Norrland [1]. Westerås.

Jansson, S. B. F. 1977. Runinskrifter i Sverige. Stockholm.

Jansson, V. 1951. Nordiska vin-namn. (Studier till en svensk ortnamnsatlas 8.) Uppsala.

JHD Jämtlands och Härjedalens diplomatarium 1-. 1943 ff. Östersund.

Jonzon, B. G. 1899. Helsingarnes kristnande och deras förhållande till Gustaf Vasas befrielsestrid och kyrkoreformation. Upsala.

Jonzon, I. 1973. Kring Hälsingland och dess gamla folkland. Ljusdal.

JR Jämtländska räkenskaper 1564-1571 1-2. 1944-48. (Skrifter utg. av Jämtlands läns fornskriftsällskap 8-9.) Östersund.

Lagman, S. 1981. Östergötlands medeltida sockennamn. (Ortnamn och samhälle 7.) Uppsala.

LDLV Libri memoriales capituli Lundensis. [Ed. by] V. Weeke. 1884-89. København.

Liedgren, J. 1981. Major Johan Blanck och de gamla bren om Lingarö och Gackerön. Hälsingerunor. 1981. Norrala.

Lind, E. H. 1905-15. Norsk-isländska dopnamn ock fingerade namn frän medeltiden. Uppsala.

Lindberg, C. 1933. Ullvi och Hov. Jämten. Östersund.

Lindén, B. 1954. Dalska namn- och ordstudier gällande särskilt Mora tingslag och Österdalsområdet 1, 3. Svenska landsmäl B, 57. Stockholm.

Lindqvist, S. 1918. Åker och Tuna. Fornvännen 13. Stockholm.

Lundberg, O. \& Sperber, H. 1911. Härnevi. (Meddelanden från Nordiska seminariet 4.) Uppsala.

Lundgren, M. F. 1878. Språkliga intyg om hednisk gudatro i Sverige. Göteborg.

Löfgren, E. 1922. Det nutida Njurunda 1. Sundsvall.

Müller, G. 1968. Altnordisch Vifill - ein Weihename. Festschrift für Otto Höfler zum 65. Geburtstag 2. Hrsg. von H. Birkhan \& O. Gschwandtler. Wien.

M̈̈U Hellbom, A. 1972. Medelpads äldre urkunder. (Det gamla Medelpad 8.) Sundsvall.

Nordlander, J. 1881. Minnen af heden tro och kult i norrländska ortnamn. Hernösand.

- 1903. Medelpads äldre bynamn. Norrländska samlingar 1. Stockholm.

Öberg, A. 1979. Olika typer av sockennamn $i$ Sverige. (Ortnamn och samhälle 6.) Uppsala. 
Olsen, M. 1915. Hedenske kultminder i norske stedsnavne. (Skrifter utg. av Videnskapsselskapet i Kristiania. 2. Hist.-filos. Klasse 1914, 4.) Kristiania. Olsen, O. 1966. Hørg, hov og kirke. København.

Olsson, I. 1976. Gotlands Stavgardar. Gotlandica 10. Visby.

Pamp, B. 1983. Ortnamn i Skåne. Stockholm.

Palm, D. 1931. Torps bynamn - ett stycke kulturhistoria. Torps socken 2. Torp.

- 1944. Bynamn och bebyggelse i Njurunda. Alsta 19. Alsta.

Palm, Th. 1940. Stav och blotträ. Namn och bygd 28. Uppsala.

Rostvik, A. 1967. Har och harg. (Studier till en svensk ortnamnsatlas 11.) Uppsala.

- 1969. Ortnamnet Harv. Namn och bygd 57. Uppsala.

Selinge, K.-G. 1974. Fångstgropar. (Fornvårdaren 12.) Östersund.

- 1976. Människan i landskapet. (Fornvårdaren 14.) Östersund.

SOVn Sveriges ortnamn. Ortnamnen i Västernorrlands län 1-4. $1955 \mathrm{ff.}$ Uppsala.

Ståhl, H. 1980-82. Stav-. Kulturhistorisk leksikon for nordisk middelalder 17. [København].

Vikingerne ved Volga. Ibn Fadlans rejsebeskrivelse. 1981. [Ed. by] J. Bæk Simonsen. Højbjerg.

Vries, J. de 1956-57. Altgermanische Religionsgeschichte 1-2. (Grundriss der germanischen Philologie 12, 1-2.) Berlin.

Wahlberg, M. 1975. Sockennamnet Sighridhakirkia. Ortnamnssällskapets $i$ Uppsala ärsskrift. Uppsala.

Wessén, E. 1921-22. Forntida gudsdyrkan i Östergötland. Meddelanden från Ostergötlands fornminnes- och museiförening. Linköping.

- 1923. Minnen av forntida gudsdyrkan i Mellan-Sveriges ortnamn. Studier $i$ nordisk filologi 14 . Helsingfors. 